\title{
Detection of inborn error of metabolisms by urine organic acid GC-MS in Southern China
}

\author{
MinYan Jiang*, Li Liu, HuiFen Mei, XiuZhen Li, Jing Cheng, YanNa Cai, Wen Zhang, XiaoJian Mao, ZhiKun Lu \\ From 7th APPES Biennial Scientific Meeting \\ Nusa Dua, Bali. 14-17 November 2012
}

\section{Background}

Inborn error of metabolisms (IEM) have been detected worldwide using gas chromatography mass spectrometry since 1980s, but few related date presently exit in Southern China. This study aimed to evaluate the prevalence, spectrum and clinical presentation of IEM in Southern China.

\section{Method}

From January 2009 to March 2012, 16075 urine samples were collected from patients with developmental delay, seizures, vomiting and metabolic acidosis in Guangzhou Women and Children's Medical Center.

\section{Results}

We diagnosed 148 cases of IEM by urine GC-MS analysis, including 97 cases of organic acid disorders, 41 cases of amion acid disorders and 10 cases of fatty acid oxidative disorders. Methylmalonic aciduria (MMA) was most common (48 cases), followed by urea cycle disorder (21 cases), phenylketonuria (20 cases), propionic aciduria (11 cases), multiple carboxylase deficiency (8 cases), glutaric aciduria type I (7 cases), oxoproliemia (7 cases), isovaleric aciduria( 6 cases), glutaric aciduris type II and Short chain acyl-CoA dehydrogenase deficiency (4 cases), 3-hydroxy-3-methylglutaric aciduria (3 cases), amionadipic aciduria (2 cases), maple syrup urine disease (2 cases), very long-china acyl-CoA dehydrogenase deficiency ( 2 cases), Malonic aciduria (1 case), Canavan disease (1 case) and mevalonic aciduria (1 case). Average age at diagnosis was 18 months. Prompt therapy was taken, including dietary and medicine treatment. Clinical improvements were observed in more than half of the patients.

Department of Endocrinology and Metabolisms, Guangzhou Women and Children's Medical Center, Guangzhou, Guangdong, China

\section{Conclusion}

In Southern China, the majority of IEM were organic acid disorders and amino acid disorders. Fatty acid oxidation disorders were relatively rare. The age at diagnosis was early and incidence of IEM gradually decreased with the age. Urine GC-MS was an important technique to diagnose IEM, which helped to improve patients' prognoses.

Published: 3 October 2013

doi:10.1186/1687-9856-2013-S1-P180

Cite this article as: Jiang et al:: Detection of inborn error of metabolisms by urine organic acid GC-MS in Southern China. International Journal of Pediatric Endocrinology 2013 2013(Suppl 1):P180.

Submit your next manuscript to BioMed Central and take full advantage of:

- Convenient online submission

- Thorough peer review

- No space constraints or color figure charges

- Immediate publication on acceptance

- Inclusion in PubMed, CAS, Scopus and Google Scholar

- Research which is freely available for redistribution

Submit your manuscript at www.biomedcentral.com/submit
() Biomed Central 